JURNAL MEDIA INFORMATIKA BUDIDARMA

Volume 4, Nomor 3, Juli 2020, Page 735-743

ISSN 2614-5278 (media cetak), ISSN 2548-8368 (media online)

Available Online at https://ejurnal.stmik-budidarma.ac.id/index.php/mib

DOI 10.30865/mib.v4i3.2220

\title{
Perancangan Sistem Informasi Laporan Asset Berbasis Smartphone dengan Metode Waterfall
}

\author{
Budi Dwi Kurniawan', Septi Andryana ${ }^{2, *}$, Benrahman ${ }^{3}$ \\ Fakultas Teknologi Komunikasi dan Informasi, Informatika, Universitas Nasional, Jakarta, Indonesia \\ Email : ${ }^{1}$ Budi.dwik@gmail.com, ${ }^{2, *}$ septi.andryana@civitas.unas.ac.id, ${ }^{3}$ Benrahman@ civitas.unas.ac.id \\ Email Penulis Korespondensi: septi.andryana@civitas.unas.ac.id
}

\begin{abstract}
Abstrak-Perkembangan dalam melaporkan asset di Universitas Nasional belum efektif. Karena banyaknya asset yang ada menyulitkan pekerja untuk merekap laporan asset. Seperti laporan asset masuk dan keluar serta status keadaan asset. Oleh kare na itu, dirancanglah Perancangan Sistem Informasi Laporan Asset Berbasis Smartphone Dengan Metode Waterfall sehingga pekerja bisa melaporkan data asset menggunakan smartphone yang lebih efisien dalam segi waktu maupun tenaga. Hasil uji coba aplikasi untuk melaporkan data asset, aplikasi dapat menampilkan hasil laporan berdasarkan asset masuk, asset keluar, serta status asset dengan akurat. Dalam pencarian data asset masuk sistem dapat menampilkan hasil laporan berdasarkan id transaksi, tanggal asset masuk, dan nama asset dengan tingkat akurat. Kemudian untuk melaporkan data asset keluar sistem dapat menampilkan hasil laporan berdasarkan id transaksi, tanngal keluar, dan nama asset dengan akurat.
\end{abstract}

Kata Kunci: Aplikasi, Asset, Laporan, Smartphone

\begin{abstract}
Developments in reporting assets at the National University have not been effective. Because the many assets that exist make it difficult for workers to recapitalize the asset report. Such as incoming and outgoing asset reports and asset status status. Therefore, the Smartphone-Based Asset Report Design Information System Designed with the Waterfall Method so that workers can report asset data using smartphones that are more efficient in terms of time and effort. Application trial results for reporting asset data, the application can display report results based on incoming assets, outgoing assets, and asset status accurately. In the search for asset data entered the system can display the results of reports based on transaction id, date of asset entered, and the name of the asset with an accurate level. Then to report the asset data out the system can display the results of the report based on the transaction id, exit, and the name of the asset accurately.
\end{abstract}

Keyword: Application, Asset, Reports, Smartphone

\section{PENDAHULUAN}

Teknologi smartphone saat ini sudah berkembang pesat. Penggunaan internet di Indonesia sudah mencapai 72,7 Juta pengguna atau sama dengan 28\% jumlah populasi di Indonesia. $80 \%$ dari penggunaan internet tersebut menggunakan perangkat smartphone. Dengan menggunakan smarphone personil atau petugas pemeliharaan aset akan lebih tersedia untuk melakukan pemeliharaan aset yang terencana maupun yang tidak terencana. Salah satu teknologi smartphone yang sangat membantu seseorang untuk s. Dalam penelitian, penulis menggunakan beberapa jurnal sebagai acuan. Hasil penelitian yang pertama berjudul "Pengembangan Sistem Monitoring Aset Berbasis Lokasi Pada Platform Mobile". Pada jurnal ini menggunakan bahasa pemograman Javascript dan menggunakan database MySQL[1].

Hasil penelitian kedua berjudul "Pembangunan Aplikasi Scheduled Maintenance System Berbasis Mobile Untuk Fixed Asset Di PT. Angkasa Pura I (Persero) Bandara Achmad Yani Semarang” pada jurnal ini menggunakan bahasa pemrograman Java dengan database yang digunakan adalah MySQL[2]. Hasil penelitian ketiga berjudul "Aplikasi Penghitungan Nilai Penyusutan Asset Dan Pencatatan Arus Kas Berbasis Android". Pada jurnal ini menggunakan bahasa Java dengan database SQLite[3]. Hasil penelitian keempat berjudul "Pengolahan Aset Berbasis Mobile Dengan Algoritma Perceptron". Pada jurnal ini menggunakan bahasa pemrograman Java dan database yang digunakan adalah MySQL[4]. Hasil penelitan kelima berjudul "Sistem Manajemen Inventori Komputer Menggunakan Near Field Communication Berbasis Android (Studi Kasus Di STIE Pelita Indonesia Pekanbaru)". Pada jurnal ini menggunakan bahasa pemrograman Java, PHP dan menggunakan database Mysq1[5].

Hasil penelitian keenam berjudul "Sistem Informasi Manajemen Aset Menggunakan Pendekatan MVC Dengan Framework Codeigniter Di PT. H-TECH Oilfield Equipment". Pada jurnal ini menggunakan bahasa pemrograman java[6]. Hasil penelitian ketujuh berjudul "Rancangan Sistem Informasi Manajemen Aset Kantor Studi Kasus: PT. Mediatama Anugrah Citra". Pada jurnal ini menggunakan bahasa pemrograman Javascript dan database MySQL, menggunakan metode waterfall[7]. Hasil penelitian kedelapan berjudul "Sistem Informasi Manajemen Aset (Simaset) Perkebunan Kelapa Sawit Pada PT. Treekreasi Margamulia Palembang". Pada jurnal ini menggunakan bahasa pemrograman Javascript[8]. Hasil penelitian kesembilan berjudul "Perancangan Sistem Informasi Data Asset Organisasi Tatalaksana Dan Administrasi Peningkatan Aparatur Pada Kantor Walikota Pematangsiantar". Pada jurnal ini menggunakan bahasa pemrograman Java dan database MySQL[9]. Hasil penelitian kesepuluh berjudul "Sistem Informasi Permintaan Dan Pengadaan Barang Untuk Instalasi VSAT Di PT. Telkomsat". Pada jurnal ini menggunakan bahasa pemrograman Java[10]. 
JURNAL MEDIA INFORMATIKA BUDIDARMA

Volume 4, Nomor 3, Juli 2020, Page 735-743

ISSN 2614-5278 (media cetak), ISSN 2548-8368 (media online)

Available Online at https://ejurnal.stmik-budidarma.ac.id/index.php/mib

DOI 10.30865/mib.v4i3.2220

Hasil penelitian kesebelas berjudul "Sistem Informasi Manajemen Aset IT Di PT. Nissin Foods Indonesia". Pada jurnal ini menggunakan bahasa pemograman PHP dan MySQL sebagai database server, menggunakan metode blackbox testing[11]. Hasil penelitian keduabelas berjudul "Pembangunan Sistem Informasi Manajemen Aset Perusahaan Penyedia Layanan Internet PT. Blitzspot Network Solution". Pada jurnal ini menggunakan bahasa pemrograman PHP dengan framework Codeigniter dan Mysql sebagai database, metode yang digunakan waterfall[12]. Hasil penelitian ketigabelas berjudul "Sistem Inventori Manajemen Aset Berbasis Teknologi Informasi”. Pada jurnal ini menggunakan bahasa pemograman PHP dan HTML dengan database server Mysql[13].

\section{METODE PENELITIAN}

\subsection{Metode Waterfall}

Metode yang digunakan dalam penelitian ini adalah waterfall, karena model ini memiliki konsep desain yang kuat serta dokumentasi yang ekstensif dari seluruh proses didasari oleh perancanaan yang akurat pada awal penelitian. Berikut ini beberapa tahapannya:

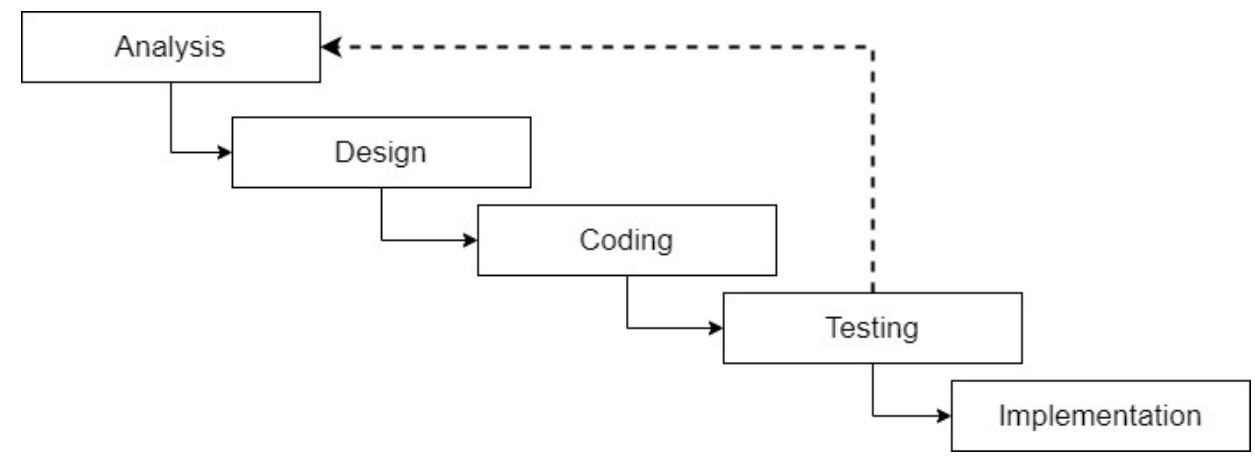

Gambar 1. Metode Waterfall

Berikut penjelasan metode Waterfall

a. Analysis

Pada proses ini dilakukan analisa kebutuhan sistem untuk dapat mengetahui fungsi apa saja yang akan dibuat. Perolehan data awal dilakukan dengan cara observasi atau datang dan menganalisis langsung pada perusahaan. Kemudian dilakukan wawancara pada pihak yang berkaitan untuk mendapatkan data yang dibutuhkan.

b. Design

Proses ini digunakan untuk mengubah kebutuhan-kebutuhan diatas menjadi representasi ke dalam bentuk blueprint software sebelum coding dimulai. Desain harus dapat mengimplementasikan kebutuhan yang telah disebutkan pada tahap sebelumnya. Desain sistem akan digambarkan dalam United Modeling Language (UML).

c. Coding

Untuk dapat dimengerti oleh mesin, dalam hal ini adalah komputer, maka desain tadi harus diubah bentuknya menjadi bentuk yang dapat dimengerti oleh mesin, yaitu ke dalam bahasa pemrograman melalui proses coding.

d. Testing

Setelah sistem sudah menjadi suatu perangkat lunak yang siap pakai, kemudian dilakukan proses Pengujian. Pengujian ini dilakukan untuk menemukan kesalahan dan menyesuaikan sistem yang telah dibangun dengan rancangan awal yang telah dibuat.

e. Implementation

Perangkat lunak yang telah diuji dan diterima pelanggan siap untuk digunakan.

\subsection{Tahapan Penelitian}

Tahapan penelitian dilakukan agar jalannya penelitian menjadi sistematis. Tahapan metode penelitian dapat dilihat pada gambar flowchart. 
JURNAL MEDIA INFORMATIKA BUDIDARMA

Volume 4, Nomor 3, Juli 2020, Page 735-743

ISSN 2614-5278 (media cetak), ISSN 2548-8368 (media online)

Available Online at https://ejurnal.stmik-budidarma.ac.id/index.php/mib

DOI 10.30865/mib.v4i3.2220

\section{a. Studi Literatur}

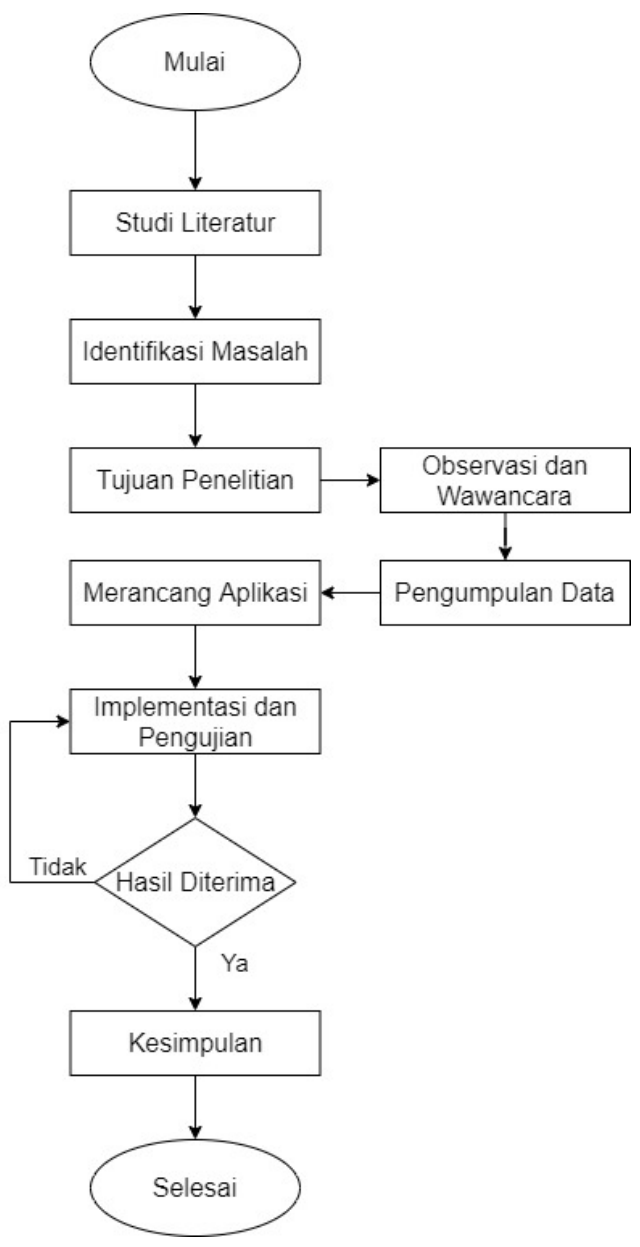

Gambar 2. Metodelogi Penelitian

Studi literatur sangat diperlukan untuk mendapatkan pemahaman yang lebih mengenai data yang diingikan beserta komponen-komponen untuk merancang aplikasi seperti bahasa pemograman php, framework codeigniter, database mysql dan aplikasi pemograman visual studio code. Dengan mempelajari berbagai referensi dari jurnal penelitian sebelumnya yang terkait dengan kebutuhan penelitian

\section{b. Identifikasi Masalah}

Identifikasi masalah yaitu melakukan identifikasi pada masalah pencarian data yang belum efektif sehingga pengguna harus mencari data satu persatu yang membutuhkan waktu dan tenaga yang lama. Hal ini berpotensi menimbulkan kesalahan yang dilakukan oleh pengguna seperti kurang teliti sehingga data yang diinginkan tidak sesuai.l

\section{c. Tujuan Penelitian}

Tujuan peneliti Observasi dengan melakukan pengamatan langsung terhadap sistem yang berjalan sesuai dengan alur data dan prosedur. Wawancara untuk mencari dan mengumpulkan data dengan cara langsung dengan staff operasional dan juga eksekutif dengan objek penelitian.

\section{d. Implementasi dan Pengujian}

Tahap setelah proses yang ada didalam sistem adalah tahap uji coba yang dibuat. Semua data hasil ujicoba dicatat secara lengkap untuk selanjutnya di analisa. analisa dilakukan dengan menentukan apakah sistem presensi ini sudah sesuai yang diharapkan atau tidak. Jika belum sesuai, maka alur penelitian akan diulangi dari tahap perancangn sistem.

\section{HASIL DAN PEMBAHASAN}

Pada perancangan aplikasi, dimana aplikasi dirancang menggunakan bahasa pemrograman PHP serta Framework 
JURNAL MEDIA INFORMATIKA BUDIDARMA

Volume 4, Nomor 3, Juli 2020, Page 735-743

ISSN 2614-5278 (media cetak), ISSN 2548-8368 (media online)

Available Online at https://ejurnal.stmik-budidarma.ac.id/index.php/mib

DOI 10.30865/mib.v4i3.2220

Codeigniter dan Bootstrap sebagai desain aplikasi, database yang digunakan adalah MySQL dan untuk teks editor menggunakan Visual Studio Code. Tahap ini juga menjelaskan semua alur proses yang ada di dalam sistem, mulai dari login hingga melakukan input asset masuk dan keluar serta, laporan berupa format pdf menggunakan flowchart.
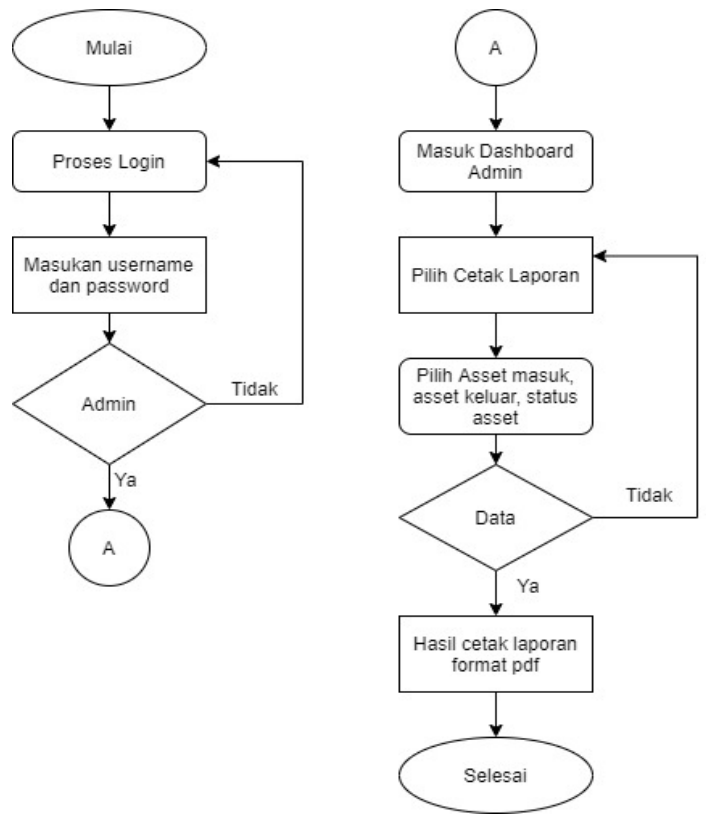

Gambar 3. Proses Login sampai Cetak Laporan

Dalam gambar 2 di atas proses login dilakukan dengan menginputkan Username dan password pada form login, jika bukan admin maka pengguna harus mengulangi proses login. Jika terdaftar maka pengguna akan diarahkan ke dashboard admin, dan kemudian dapat memilih menu cetak laporan. Di halaman tersebut pengguna dapat mencetak laporan asset berdasarkan asset masuk, asset keluar dan status asset. Jika data sesuai maka sistem akan mengunduh file pdf, jika tidak sistem akan memberi pesan bahwa data yang dicetak tidak ada.

\section{a. Rancangan Use Case}

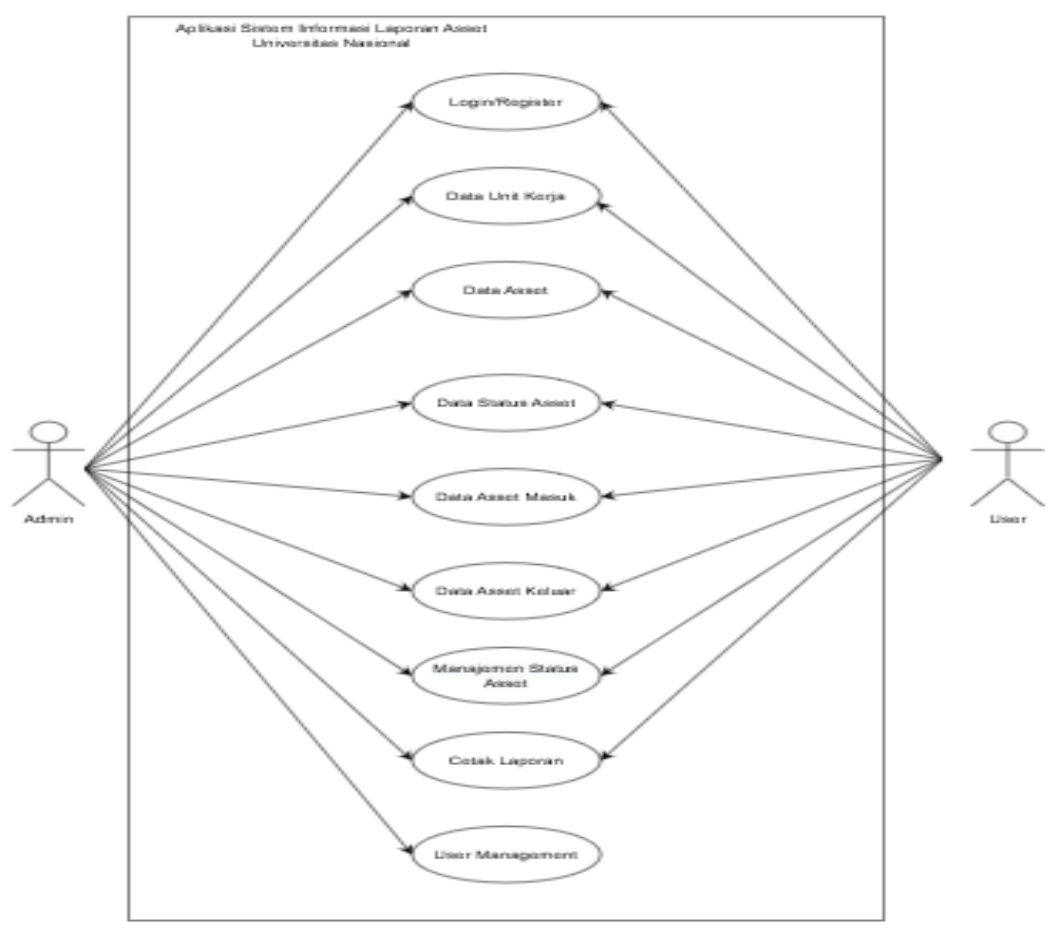

Gambar 4. Use Case Diagram 
JURNAL MEDIA INFORMATIKA BUDIDARMA

Volume 4, Nomor 3, Juli 2020, Page 735-743

ISSN 2614-5278 (media cetak), ISSN 2548-8368 (media online)

Available Online at https://ejurnal.stmik-budidarma.ac.id/index.php/mib

DOI 10.30865/mib.v4i3.2220

Dalam sistem ini admin dapat melakukan login, kemudian dapat mengakses data unit kerja, data asset, data status asset, data asset masuk, data asset keluar, data manajemen status asset dan melakukan input, edit, hapus terhadap data tersebut berdasarkan kategori yang telah ditentukan. admin juga dapat mengakses user management yang berfungsi untuk mengaktifkan user apabila ada user baru yang mendaftar, sedangkan user harus diaktifkan terlebih dahulu oleh admin apabila ingin login aplikasi.

\section{b. Activity Diagram}

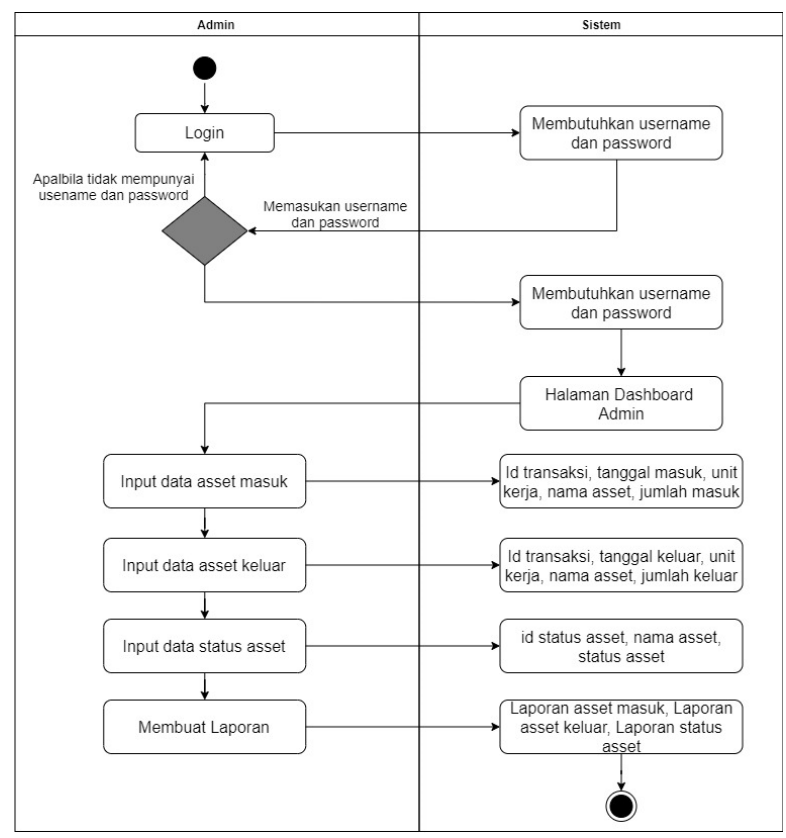

Gambar 5. Activity Diagram

Admin melakukan login, sistem membutuhkan username dan password untuk login, kemudian sistem akan memproses username dan password yang masuk. Jika data tidak ada maka ulangi proses login, jika data ada masuk ke halaman utama. Admin melakukan input data asset masuk, asset keluar, status asset, dan membuat laporan hasil inputan. Kemudian sistem dapat menampilkan data yang sudah diinput dan menampilkan hasil laporan.

\section{c. Statechart Diagram}

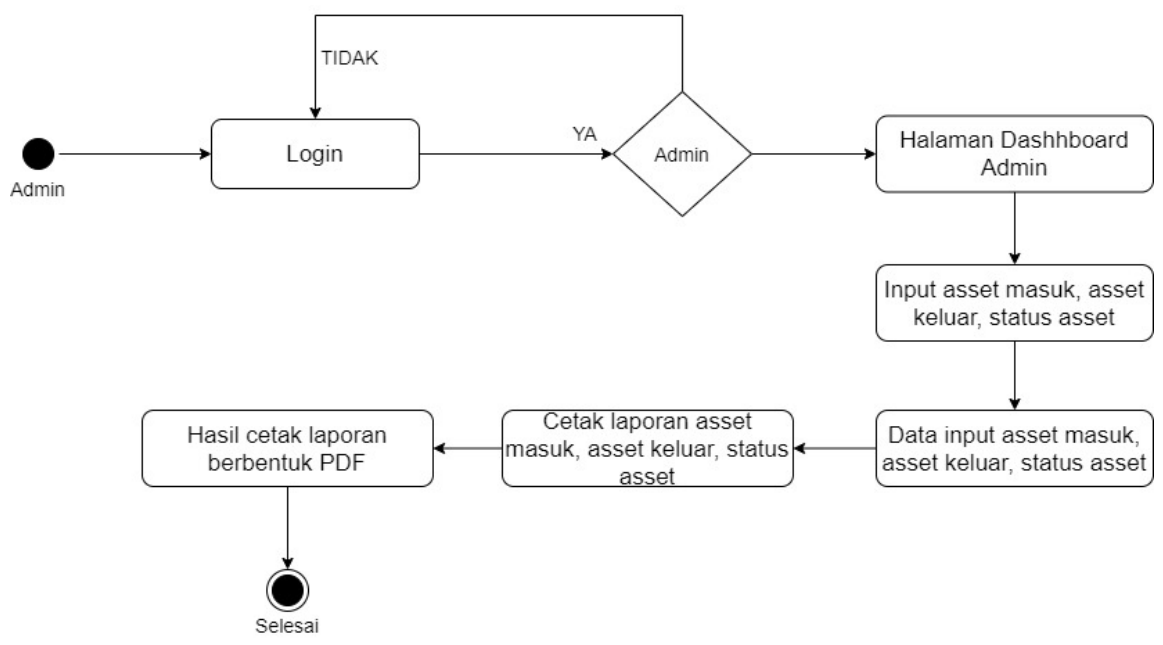

Gambar 6. Statechart Diagram

Admin melakukan login, jika berhasil akan masuk ke halaman dashboard admin, jika gagal akan kembali ke halaman login. Admin melakukan input data asset masuk, asset keluar, status asset, dan membuat laporan hasil inputan. Kemudian sistem dapat menampilkan data yang sudah diinput dan menampilkan hasil laporan berbentuk PDF. 
JURNAL MEDIA INFORMATIKA BUDIDARMA

Volume 4, Nomor 3, Juli 2020, Page 735-743

ISSN 2614-5278 (media cetak), ISSN 2548-8368 (media online)

Available Online at https://ejurnal.stmik-budidarma.ac.id/index.php/mib

DOI 10.30865/mib.v4i3.2220

\section{d. ERD (Entity Relation Diagram)}

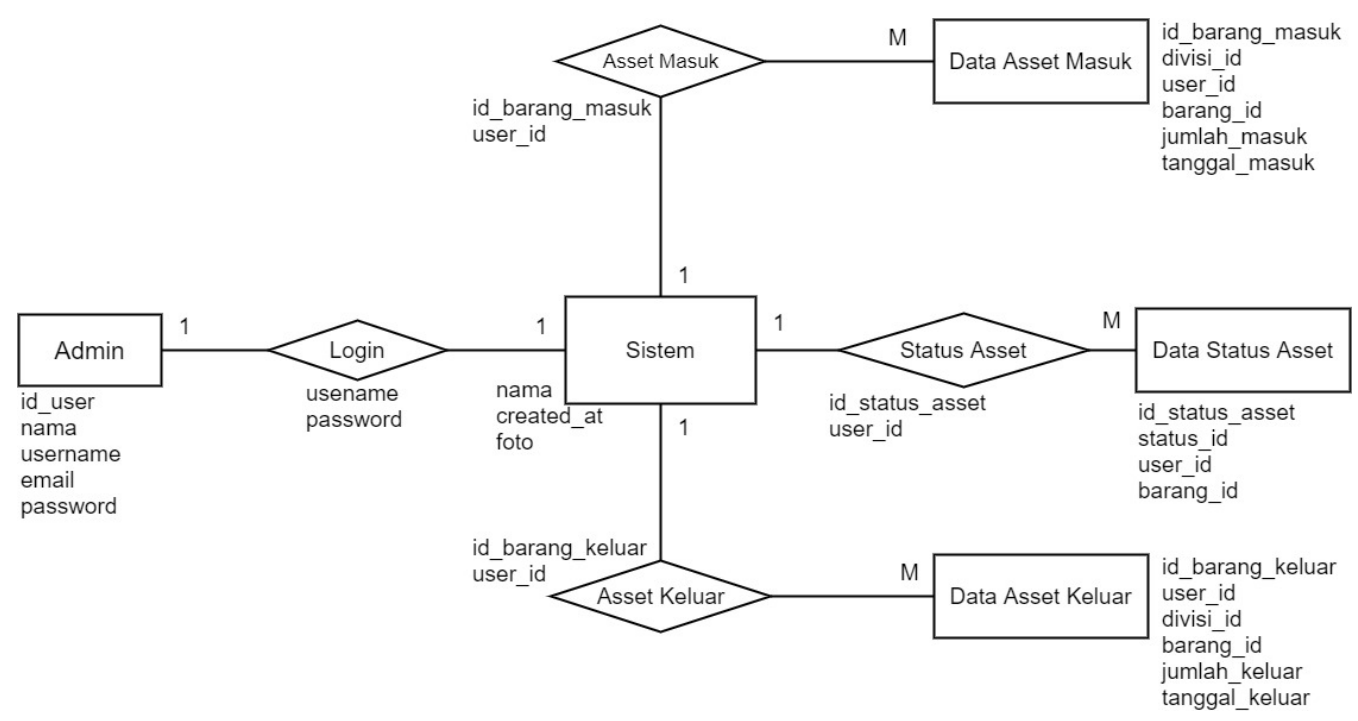

Gambar 7. ERD (Entity Relation Diagram)

\subsection{Pengujian Aplikasi}

\section{a. Halaman Login}

Admin/User harus menginput username dan password kedalam form login jika username dan password terdaftar maka admin/user akan diteruskan ke dashboard, jika ada pesan error pada form login user harus mengulangi proses login.

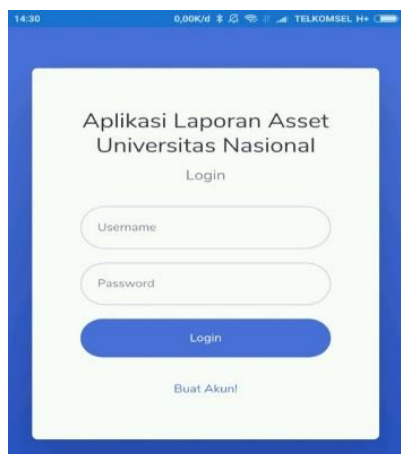

Gambar 8. Halaman login

\section{b. Halaman Dashboard}

Berikut tampilan halaman dashboard

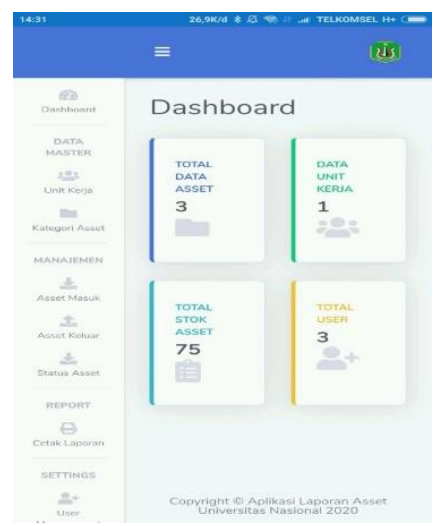

Gambar 9. Halaman dashboard admin 
JURNAL MEDIA INFORMATIKA BUDIDARMA

Volume 4, Nomor 3, Juli 2020, Page 735-743

ISSN 2614-5278 (media cetak), ISSN 2548-8368 (media online)

Available Online at https://ejurnal.stmik-budidarma.ac.id/index.php/mib

DOI 10.30865/mib.v4i3.2220

\section{c. Halaman Asset Masuk}

Berikut merupakan tampilan input yang bertujuan untuk menginputkan Asset Masuk.

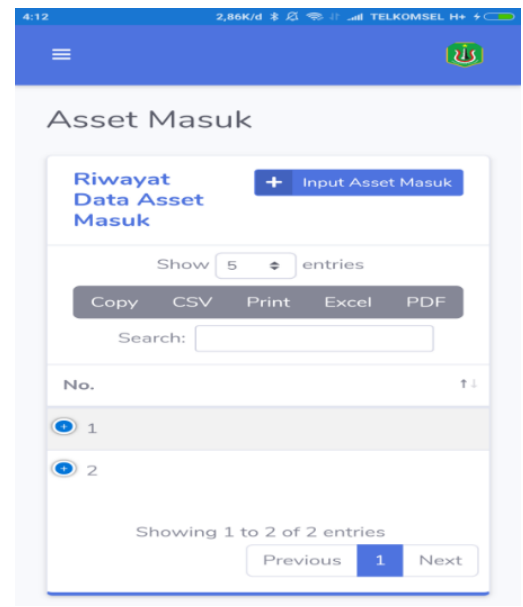

Gambar 10. Data asset masuk

\section{d. Halaman Asset Keluar}

Berikut merupakan tampilan input yang bertujuan untuk menginputkan Asset Keluar.

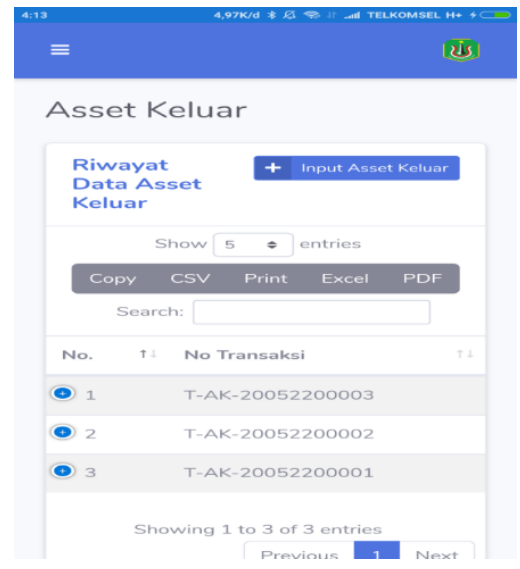

Gambar 11. Data asset keluar

\section{e. Halaman Status Asset}

Berikut merupakan tampilan untuk melihat status Asset.

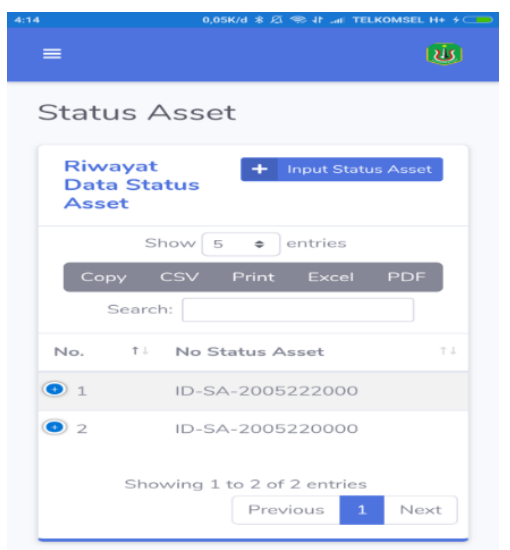

Gambar 12. Data status asset 
JURNAL MEDIA INFORMATIKA BUDIDARMA

Volume 4, Nomor 3, Juli 2020, Page 735-743

ISSN 2614-5278 (media cetak), ISSN 2548-8368 (media online)

Available Online at https://ejurnal.stmik-budidarma.ac.id/index.php/mib

DOI $10.30865 / \mathrm{mib} . v 4 \mathrm{i} 3.2220$

\section{f. Halaman Laporan}

Berikut merupakan tampilan halaman laporan Asset

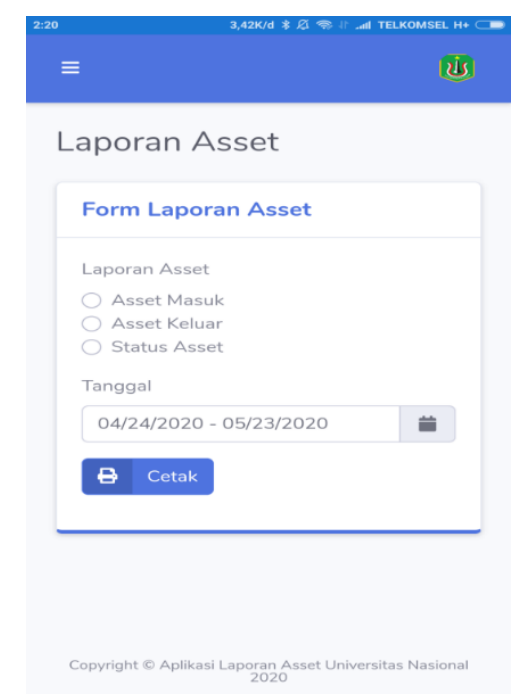

Gambar 13. Halaman form laporan

Hasil laporan terlihat seperti berikut ini

Laporan

Tanggal : 04/24/2020 - 05/23/2020

\begin{tabular}{|c|c|c|l|l|c|}
\hline No. & Tgl Masuk & \multicolumn{1}{|c|}{ ID Transaksi } & Nama Asset & Unit Kerja & Jumlah Masuk \\
\hline 1. & $2020-05-22$ & T-AM-20052200002 & HP Notebook-14s & FTKI & 6 Unit \\
\hline 2. & $2020-05-22$ & T-AM-20052200001 & Samsung Galaxy J1 Ace & FTKI & 10 Unit \\
\hline
\end{tabular}

Gambar 14. Pdf laporan asset masuk

\section{KESIMPULAN}

Penggantian proses manual menjadi aplikasi mobile sangat membantu dalam hal efisisen waktu, ketepatan data, penyajian informasi riwayat asset, penyajian informasi kejadian, dan pelaporan bulanan. Sistem yang dibangun juga akan dirancang untuk memberikan notifikasi terhadap departemen terkait yang akan menangani apabila terjadi keadaan yang tidak normal. Pelaporan aset yang dapat dilakukan melalui aplikasi mobile maupun web akan mewujudkan efesiensi waktu dan tenaga.

\section{REFERENCES}

[1] M. Rizal, H. Tolle, and L. Fanani, "Pengembangan Sistem Monitoring Aset Berbasis Lokasi Pada Platform Mobile," vol. 3, no. 2, p. 102, 2018.

[2] P. Aplikasi, S. Maintenance, A. Penelitian, A. Pura, Q. R. Code, and Q. R. Code, "Pembangunan Aplikasi Scheduled Maintenance... (Naraiswara dkk.)," pp. 110-115, 2017.

[3] S. Si, M. Kom, J. Komputer, T. Informatika, F. Sains, and U. K. Immanuel, "APLIKASIPENGHITUNGANNILAIPENYUSUTAN ASSET DANPENCATATANARUSKAS BERBASIS ANDROID," vol. 07, no. 02, pp. 42-55, 2015.

[4] L. Hakim and J. Giovanni, "Fakultas Teknologi dan Desain," Univ. Bunda Mulia JL. Lodan Raya, vol. 2015, no. 2, p. 6909712, 2015.

[5] M. L. Hamzah and A. A. Purwati, "Sistem Manajemen Inventori Komputer Menggunakan Near Field Communication Berbasis Android Studi Kasus di STIE Pelita Indonesia Pekanbaru,” J. Econ. Bussines Account., vol. 1, no. 1, pp. 95-104, 2017, doi: 10.31539/costing.v1i1.46. 


\section{JURNAL MEDIA INFORMATIKA BUDIDARMA}

Volume 4, Nomor 3, Juli 2020, Page 735-743

ISSN 2614-5278 (media cetak), ISSN 2548-8368 (media online)

Available Online at https://ejurnal.stmik-budidarma.ac.id/index.php/mib

DOI 10.30865/mib.v4i3.2220

[6] J. Friadi and Athailah, "Sistem Informasi Manajemen Aset Menggunakan Pendekatan Mvc Dengan Framework Codeigniter Di Pt. H-Tech Oilfield Equipment," Zo. Komput., vol. 7, no. 3, pp. 1-16, 2017.

[7] A. J. Nathan and A. Scobell, "Jurnal Manajemen Sistem Informasi dan Teknologi,” Sist. Inf. dan Teknol., vol. 91, no. 5, pp. 1689-1699, 2012, doi: 10.1017/CBO9781107415324.004.

[8] E. H. Syamiri, D. Kurnianto, and S. Maramis, "Sistem Informasi Manajemen Aset (SIMASET) Perkebunan Kelapa Sawit pada PT. Treekreasi Margamulia Palembang," JTIM J. Teknol. Inf. dan Multimed., vol. 1, no. 3, pp. 221-228, 2019, doi: 10.35746/jtim.v1i3.41.

[9] C. Wulandari, D. Suhendro, S. M. Informatika, and S. K. Akuntansi, "Perancangan Sistem Informasi Data Asset Organisasi," vol. 3, no. 1, pp. 56-67, 2020.

[10] U. Instalasi, V. Di, and P. T. Telkomsat, "SISTEM INFORMASI PERMINTAAN DAN PENGADAAN BARANG," JRAMI, vol. 01, no. 01, pp. 126-133, 2020.

[11] R. L. Winata and S. Rahayu, "SISTEM INFORMASI MANAJEMEN ASET IT DI PT . NISSIN FOODS INDONESIA," $J$. Cendikia, vol. XVIII, no. vol 18, pp. 331-337, 2019.

[12] M. Arif Latama, T. H. Pudjiantoro, and P. N. Sabrina, "Pembangunan Sistem Informasi Manajemen Aset Perusahaan Penyedia Layanan Internet Pt. Blitzspot Network Solution,” Pros. SNST ke-10 Tahun 2019, pp. 89-94, 2019.

[13] R. dan A. P. W. Paryati, "Sistem inventori manajemen aset berbasis teknologi informasi 1)," TEDC, vol. 13, no. 3, pp. 276$282,2019$. 